\title{
Cholinergic regulation of protein phosphorylation in bovine adrenal chromaffin cells
}

(tyrosine hydroxylase/“‘100-kDa"/“‘87-kDa"/protein III)

\author{
John W. Haycock*, Michael D. Browning ${ }^{\dagger}$, and Paul Greengard \\ Laboratory of Molecular and Cellular Neuroscience, The Rockefeller University, 1230 York Avenue, New York, NY 10021-6399 \\ Contributed by Paul Greengard, October 10, 1986
}

\begin{abstract}
Chromaffin cells were isolated from bovine adrenal medullae and maintained in primary culture. After prelabeling with ${ }^{32} \mathrm{PO}_{4}$, exposure of the chromafifin cells to acetylcholine increased the phosphorylation of a $M_{\mathrm{r}} \approx \mathbf{1 0 0 , 0 0 0}$ protein and a $M_{\mathrm{r}} \approx 60,000$ protein (tyrosine hydroxylase), visualized after separation of total cellular proteins in $\mathrm{NaDodSO}_{4} /$ polyacrylamide gels. Immunoprecipitation with antibodies to three known phosphoproteins ("100-kDa," "87kDa," and protein III) revealed an acetylcholine-dependent phosphorylation of these proteins. These three proteins were also shown to be present in bovine adrenal chromafinn cells by immunolabeling techniques. " $100-\mathrm{kDa} "$ is a $M_{\mathrm{r}} \approx 100,000$ protein selectively phosphorylated by calcium/calmodulindependent protein kinase III, “87-kDa" is a $M_{\mathbf{r}} \approx \mathbf{8 7 , 0 0 0}$ protein selectively phosphorylated by protein kinase $\mathbf{C}$, and protein III is a phosphoprotein doublet of $M_{r} \approx 74,000$ (IIIa) and $M_{r} \approx 55,000$ (III) phosphorylated by cAMP-dependent protein kinase and calcium/calmodulin-dependent protein kinase I. Furthermore, 100-kDa was shown to be identical to the $M_{\mathrm{r}} \approx 100,000$ protein whose phosphorylation was increased by acetylcholine treatment. The acetylcholine-dependent increase in phosphorylation of tyrosine hydroxylase, 100-kDa, 87-kDa, and protein III required extracellular calcium and was mimicked by nicotine, veratridine, elevated $\mathrm{K}^{+}$, and calcium ionophore A23187, but not by muscarine. In addition, forskolin increased the phosphorylation of tyrosine hydroxylase, 100kDa, and protein III, but not that of 87-kDa. Phorbol 12,13dibutyrate increased the phosphorylation of tyrosine hydroxylase, 87-kDa, and protein III, but not that of 100-kDa. The data demonstrate that cholinergic activation of chromafinin cells increases the phosphorylation of several proteins and that several protein kinase systems may be involved in these effects.
\end{abstract}

Acetylcholine, released from the splanchnic nerve, causes the exocytosis of catecholamines from bovine adrenal medullary chromaffin cells (1-4). Cholinergic activation of chromaffin cells also increases the phosphorylation of a $M_{\mathrm{r}}$ $\approx 100,000$ protein and a $M_{\mathrm{r}} \approx 60,000$ protein $(5)$. The $M_{\mathrm{r}}$ $\approx 60,000$ protein was shown to be tyrosine hydroxylase $(6-8)$, but the $M_{\mathrm{r}} \approx 100,000$ protein has remained uncharacterized.

We have examined chromaffin cells for the presence and phosphorylation of several phosphoproteins whose phosphorylation state is known to be increased in nerve terminals by treatments that induce transmitter release. In neuronal tissues, such as synaptosomes and brain slices, depolarization produces a calcium-dependent increase in the phosphorylation state of " $87-\mathrm{kDa}$ " (9) [an acidic, $M_{\mathrm{r}} \approx 87,000$ protein present in a wide variety of mammalian tissues but most prominent in brain (10)] and protein III (11-13) [a phosphoprotein doublet of $M_{\mathrm{r}} \approx 74,000$ (IIIa) and $M_{\mathrm{r}} \approx 55,000$ (IIIb) associated with synaptic vesicles in brain (14-16)]. In addi-

The publication costs of this article were defrayed in part by page charge payment. This article must therefore be hereby marked "advertisement" in accordance with 18 U.S.C. $\$ 1734$ solely to indicate this fact. tion, we have evaluated the possible identity of the $M_{\mathrm{r}}$ $\approx 100,000$ chromaffin cell protein with " $100-\mathrm{kDa}$," a substrate for calcium/calmodulin-dependent protein kinase III $(17,18)$. Recent experiments have shown that the phosphorylation of $100-\mathrm{kDa}$ can be regulated in other intact tissues such as human fibroblasts (31).

\section{MATERIALS AND METHODS}

Materials. Bovine adrenal chromaffin cells were isolated, purified and maintained as monolayers on collagen-coated dishes $\left(10^{6}\right.$ cells per $60-\mathrm{mm}$ dish) for $4-14$ days as described (19).

${ }^{125}$ I-labeled protein $\mathrm{A}$ and ${ }^{32} \mathrm{PO}_{4}$ were purchased from $\mathrm{New}$ England Nuclear. Acetylcholine, nicotine, muscarine, veratridine, and forskolin were purchased from Sigma. Phorbol compounds were from LC Systems. Dioctanoylglycerol was from Avanti Polar Lipids. Staphylococcus aureus V8 protease was from Miles. Trypsin and chymotrypsin were from Cooper. Calcium ionophore A23187 and Pansorbin were from Calbiochem-Behring. All other chemicals were reagent grade or better.

Determination of Levels of 100-kDa, 87-kDa, and Protein III in Chromafîn Cells by Immunolabeling. After rinsing with Hepes-buffered saline, chromaffin cells were solubilized in $1 \% \mathrm{NaDodSO}_{4}$. Various amounts of chromaffin cell protein and appropriate tissue standards were subjected to NaDod$\mathrm{SO}_{4} /$ polyacrylamide gel electrophoresis and electrophoretically transferred to nitrocellulose (BA83, Schleicher \& Schuell). The nitrocellulose sheets were incubated (20) with rabbit antibodies either to purified rat pancreas $100-\mathrm{kDa}$ (provided by $\mathrm{A}$. Nairn), to purified bovine brain $87-\mathrm{kDa}$ (provided by K. Albert), or to purified bovine brain protein III (15). The sheets were then incubated with ${ }^{125}$ I-labeled protein $A(21)$, and the immunoreactivity was visualized by autoradiography. The ${ }^{125} \mathrm{I}$ in the bands was quantitated with a Micromedic 2/200 gamma counter. Concentrations of the different proteins in chromaffin cells were then calculated on the basis of known tissue standard values [100-kDa, rat pancreas, $17 \mu \mathrm{g} / \mathrm{mg}$ of protein (18); 87-kDa, bovine brain, 2 $\mu \mathrm{g} / \mathrm{mg}$ of protein (K. Albert and P.G., unpublished data); protein IIIa, bovine brain, $0.45 \mu \mathrm{g} / \mathrm{mg}$ of protein (15); and protein IIIb, bovine brain, $0.95 \mu \mathrm{g} / \mathrm{mg}$ of protein (15)].

Protein Phosphorylation in Intact Chromafin Cells. Chromaffin cells were rinsed and prelabeled $\left(60 \mathrm{~min}, 37^{\circ} \mathrm{C}\right)$ in Hepes-buffered saline $(150 \mathrm{mM} \mathrm{NaCl} / 10 \mathrm{mM}$ Hepes $/ 5.5 \mathrm{mM}$ D-glucose $/ 5 \mathrm{mM} \mathrm{KCl} / 1 \mathrm{mM} \mathrm{MgSO} / 1 \mathrm{mM} \mathrm{CaCl} 2, \mathrm{pH} 7.4)$ containing ${ }^{32} \mathrm{PO}_{4}(1 \mathrm{mCi} / 2 \mathrm{ml}$ per $60-\mathrm{mm}$ dish; $1 \mathrm{Ci}=37$ GBq). The cells were then incubated with appropriate test substances, as indicated in Results. After incubation, the

*Present address: Department of Biochemistry, Louisiana State University Medical Center, 1100 Florida Avenue, New Orleans, LA 70119.

†Present address: Department of Pharmacology, University of Colorado Health Sciences Center, Denver, CO 80262. 


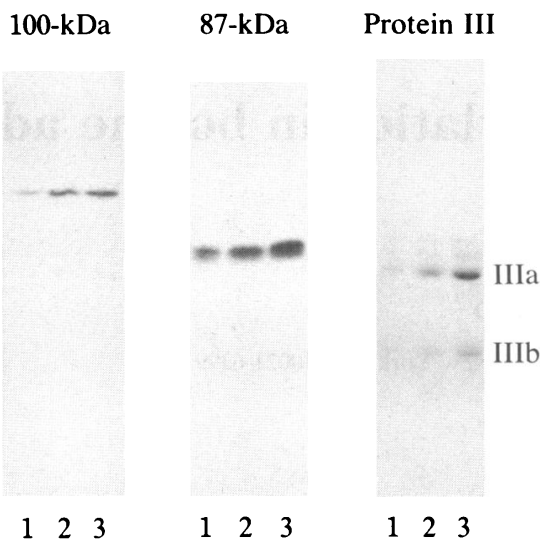

Fig. 1. Immunolabeling of $100-\mathrm{kDa}, 87-\mathrm{kDa}$, and protein III from chromaffin cells. Chromaffin cell proteins $(20,40$, and $60 \mu \mathrm{g}$, in lanes $1-3$, respectively), solubilized in $1 \% \mathrm{NaDodSO}_{4}$, were separated in $\mathrm{NaDodSO}_{4} /$ polyacrylamide gels and transferred to nitrocellulose. The nitrocellulose sheets were incubated with rabbit antibodies and developed with ${ }^{125} \mathrm{I}$-labeled protein A as described in Materials and Methods. The resultant autoradiograms are shown.

medium was aspirated and the cells were solubilized in $1 \%$ $\mathrm{NaDodSO}_{4} / 1 \mathrm{mM}$ EDTA, $\mathrm{pH} 8$. Aliquots were subjected to $\mathrm{NaDodSO}_{4} /$ polyacrylamide gel electrophoresis either directly or after immunoprecipitation with antibodies to $100-\mathrm{kDa}$, $87-\mathrm{kDa}$, or protein III. After autoradiography of stained and dried gels, ${ }^{32} \mathrm{P}$ incorporation was quantitated either by liquid scintillation counting or with an AMBIS beta scanner (Advanced Microbiology Systems).

Immunoprecipitation. Aliquots of the solubilized samples were adjusted to $150 \mathrm{mM} \mathrm{NaCl}, 50 \mathrm{mM} \mathrm{NaF}, 10 \mathrm{mM}$ Hepes (pH 7.4), 2 mM EDTA, 2 mM EGTA, 2.5\% Nonidet P-40, and $0.5 \% \mathrm{NaDodSO}_{4}$ and then precleared with Pansorbin. After incubation with antibody, antigen-antibody complexes were precipitated with fresh Pansorbin and subjected to NaDod$\mathrm{SO}_{4}$ /polyacrylamide gel electrophoresis. As evidenced by immunolabeling of the immunoprecipitates, as described above, recoveries of $87-\mathrm{kDa}$ and protein III were $\approx 100 \%$. Recovery of $100-\mathrm{kDa}$ by immunoprecipitation was not complete; however, a constant amount $(\approx 30 \%)$ was recovered from each sample.

Other Procedures. Protein was determined as described (22). $\mathrm{NaDodSO}_{4} /$ polyacrylamide gel electrophoresis was performed with $7.5 \%$ slab gels, using the method of Laemmli (23). Two-dimensional polyacrylamide gel electrophoresis (24), one-dimensional partial proteolysis maps using $S$. aureus V8 protease $(25,26)$, and phospho amino acid analysis after limit tryptic/chymotryptic digestion $(27,28)$ were performed as described.

\section{RESULTS}

100-kDa, 87-kDa, and Protein III in Chromafîn Cells. Fig. 1 illustrates, by immunolabeling, the presence of $100-\mathrm{kDa}$,

Table 1. Determination of the levels of 100-kDa, 87-kDa, and protein III in chromaffin cells by immunolabeling

\begin{tabular}{lcc}
\hline & \multicolumn{2}{c}{ Level } \\
\cline { 2 - 3 } Substrate & $\mu \mathrm{g} / \mathrm{mg}$ of protein & Molecules per cell* \\
\hline 100-kDa & 2.4 & $1.4 \times 10^{6}$ \\
87-kDa & 0.9 & $6.2 \times 10^{5}$ \\
Protein IIIa & 0.16 & $1.3 \times 10^{5}$ \\
Protein IIIb & 0.10 & $1.1 \times 10^{5}$ \\
\hline
\end{tabular}

${ }^{*}$ Calculated on the basis of apparent molecular weight in $\mathrm{NaDodSO}_{4} /$ polyacrylamide gel electrophoresis and $10^{7}$ cells per $\mathrm{mg}$ of protein.

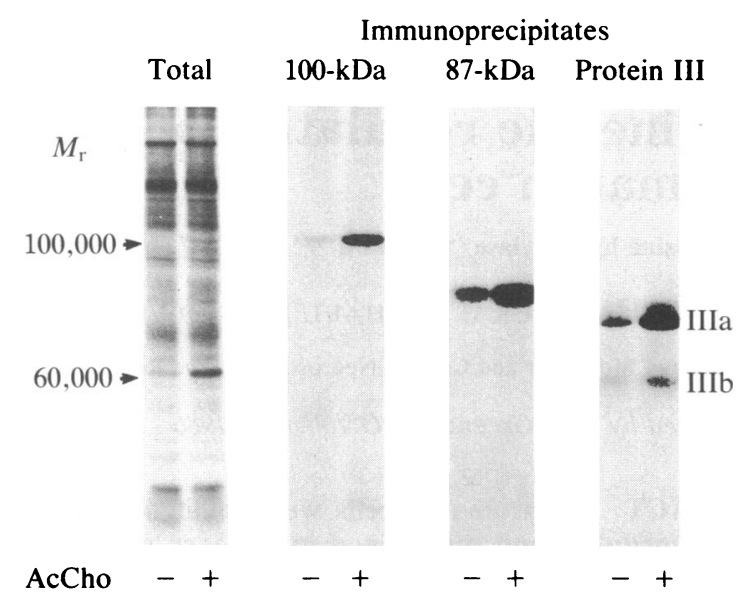

Fig. 2. Effect of acetylcholine on protein phosphorylation in chromaffin cells. After prelabeling with ${ }^{32} \mathrm{PO}_{4}$, chromaffin cells were incubated for $1 \mathrm{~min}$ in the absence $(-)$ or presence $(+)$ of $100 \mu \mathrm{M}$ acetylcholine (AcCho). Chromaffin cell proteins were solubilized in $\mathrm{NaDodSO}_{4}$ and then separated in $\mathrm{NaDodSO}_{4}$ /polyacrylamide gels either before (Total) or after (Immunoprecipitates) immunoprecipitation with antibodies to $100-\mathrm{kDa}, 87-\mathrm{kDa}$, or protein III. The resultant autoradiograms are presented.

87-kDa, and protein III in 4-day-old cultures of purified chromaffin cells. Calculations of the levels of these proteins are presented in Table 1 . The levels of these proteins remained relatively constant over the period of time in culture (4-14 days) used in these studies (data not shown).

Phosphorylation of Tyrosine Hydroxylase, 100-kDa, 87. kDa, and Protein III in Intact Chromaffin Cells. In cells prelabeled with ${ }^{32} \mathrm{PO}_{4}$, addition of acetylcholine $(100 \mu \mathrm{M}, 60$ sec) caused an increase in ${ }^{32} \mathrm{P}$ incorporation into two proteins of $M_{\mathrm{r}} \approx 100,000$ and $M_{\mathrm{r}} \approx 60,000$ that were present in $\mathrm{NaDodSO}_{4}$ extracts of total chromaffin cell protein (Fig. 2). In rare cases, as that of the experiment shown in Fig. 2,

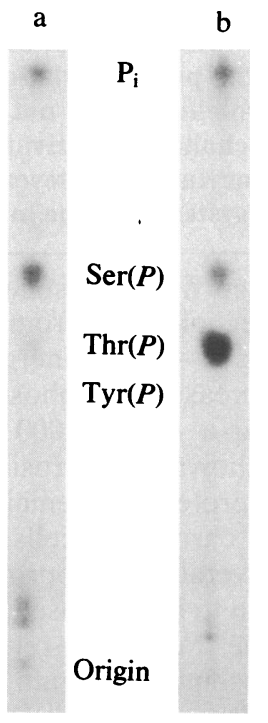

FIG. 3. Phospho amino acid analysis of the $M_{\mathrm{r}} \approx 100,000$ chromaffin cell phosphoprotein. After prelabeling with ${ }^{32} \mathrm{PO}_{4}$, chromaffin cells were incubated in the absence (lane a) or presence (lane b) of acetylcholine $(100 \mu \mathrm{M}, 60 \mathrm{sec})$. Chromaffin cell proteins were solubilized and separated in $\mathrm{NaDodSO}_{4} /$ polyacrylamide gels. After autoradiography, the $M_{\mathrm{r}} \approx 100,000$ protein bands were excised and digested with trypsin/chymotrypsin (27). The digests were hydrolyzed in $6 \mathrm{M} \mathrm{HCl}$ and electrophoresed as described (28). The resultant autoradiogram is shown. $\operatorname{Ser}(P)$, phosphoserine; $\operatorname{Thr}(P)$, phosphothreonine; $\operatorname{Tyr}(P)$, phosphotyrosine. 


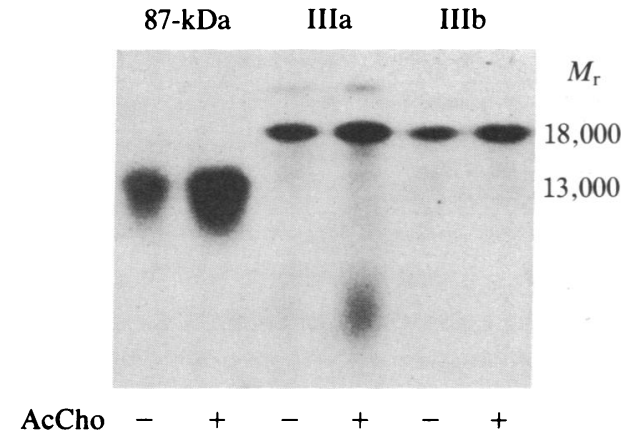

FIG. 4. Partial proteolysis of $87-\mathrm{kDa}$, protein IIIa, and protein IIIb from chromaffin cells with $S$. aureus V8 protease. After prelabeling with ${ }^{32} \mathrm{PO}_{4}$, chromaffin cells were incubated in the absence $(-)$ or presence $(+)$ of acetylcholine (AcCho, $100 \mu \mathrm{M}, 60$ $\mathrm{sec})$. Chromaffin cell proteins were solubilized and then separated in $\mathrm{NaDodSO}_{4} /$ polyacrylamide gels after immunoprecipitation with antibodies to $87-\mathrm{kDa}$ or protein III. Immunoprecipitated $87-\mathrm{kDa}$, protein IIIa, and protein IIIb were excised and subjected to limited proteolysis during $\mathrm{NaDodSO}_{4} / 15 \%$ polyacrylamide gel electrophoresis. The resultant autoradiogram is shown.

acetylcholine also caused an increase in ${ }^{32} \mathrm{P}$ incorporation into a protein of $M_{\mathrm{r}} 96,000$. Immunoprecipitation with antibodies to $100-\mathrm{kDa}, 87-\mathrm{kDa}$, and protein III revealed that acetylcholine also increased ${ }^{32} \mathrm{P}$ incorporation into $100-\mathrm{kDa}$, 87-kDa, and protein III (Fig. 2).

Identification of the $M_{\mathrm{r}} \approx 100,000$ Chromafin Cell Phosphoprotein as 100-kDa. Phosphorylation of the $M_{\mathrm{r}} \approx 60,000$ protein was described previously (5), and the protein has been identified as tyrosine hydroxylase (6-8). Phosphorylation of the $M_{\mathrm{r}} \approx 100,000$ protein was also described previously (5), but the protein was not characterized. Several lines of evidence indicate that the $M_{\mathrm{r}} \approx 100,000$ phosphoprotein evident in total cell extracts is $100-\mathrm{kDa}$. (i) Although immunoprecipitation of $100-\mathrm{kDa}$ was incomplete, the relative amount recovered was determined by immunolabeling. From this value it was possible to calculate the total amount of ${ }^{32} \mathrm{P}$ incorporated into $100-\mathrm{kDa}$. This value agreed with the value determined for ${ }^{32} \mathrm{P}$ incorporation into the $M_{\mathrm{r}} \approx 100,000$ phosphoprotein in the total chromaffin cell extract. (ii) After cells were labeled with ${ }^{32} \mathrm{PO}_{4}$ and treated with acetylcholine, total cell extracts were subjected to either one-dimensional $\mathrm{NaDodSO}_{4}$ /polyacrylamide gel electrophoresis or two-dimensional (Triton/urea, $\mathrm{NaDodSO}_{4}$ ) polyacrylamide gel electrophoresis. Immunoblots developed with antibodies to $100-\mathrm{kDa}$ and peroxidase-coupled anti-rabbit IgG (instead of ${ }^{125}$ I-labeled protein A) colocalized the $M_{\mathrm{r}} \approx 100,000{ }^{32} \mathrm{P}$ incorporation and $100-\mathrm{kDa}$ immunoreactivity (data not shown). (iii) Purified $100-\mathrm{kDa}$ is phosphorylated in vitro by calcium/calmodulin-dependent protein kinase III only on phosphothreonine residues $(17,18)$. Phospho amino acid analysis of the $M_{\mathrm{r}} \approx 100,000$ region of gels from total chromaffin cell extracts showed that, although both $\left[{ }^{32} \mathrm{P}\right]$ phosphoserine and $\left.{ }^{32} \mathrm{P}\right]$ phosphothreonine were present in the $M_{\mathrm{r}}$ $\approx 100,000$ region, acetylcholine increased ${ }^{32} \mathrm{P}$ incorporation only into phosphothreonine (Fig. 3). Furthermore, in the case of immunoprecipitated $100-\mathrm{kDa}$, only phosphothreonine was detected (data not shown). The increase in 100-kDa phosphorylation produced by acetylcholine did not appear to result from $100-\mathrm{kDa}$ phosphorylation in the small number of endothelial cells that may contaminate chromaffin cell preparations. Neither acetylcholine nor elevated $\mathrm{K}^{+}$increased 100-kDa phosphorylation in cultured endothelial cells (ref. 32 and data not shown).

Characteristics of Chromafin Cell 87-kDa and Protein III. As shown in Figs. 1 and 2, chromaffin cell 87-kDa and protein III crossreacted with antibodies specific for purified $87-\mathrm{kDa}$ and protein III. In addition, other similarities were observed. When purified $87-\mathrm{kDa}$ is phosphorylated with protein kinase $\mathrm{C}$ and subjected to partial proteolysis with $S$. aureus V8 protease, a $M_{\mathrm{r}} \approx 13,000$ phosphopeptide is produced $(9,29)$. Partial proteolysis of chromaffin cell $87-\mathrm{kDa}$ with $S$. aureus V8 protease also produced a $M_{\mathrm{r}} \approx 13,000{ }^{32} \mathrm{P}$-labeled peptide, the phosphorylation of which was increased by acetylcholine treatment (Fig. 4). When purified protein III is phosphorylated with cAMP-dependent protein kinase and subjected to partial proteolysis with $S$. aureus $\mathrm{V} 8$ protease, a prominent $M_{\mathrm{r}} \approx 18,000$ phosphopeptide and a minor $M_{\mathrm{r}} \approx 9,000$ phosphopeptide are produced $(14,15)$. Partial proteolysis of

Table 2. Comparison of the effects of acetylcholine and other secretagogues on protein phosphorylation in chromaffin cells

\begin{tabular}{lccccc}
\hline & \multicolumn{5}{c}{${ }^{32} \mathrm{P}$ incorporation, \% control } \\
\cline { 2 - 6 } \multicolumn{1}{c}{ Test substance } & $\begin{array}{c}\text { Tyrosine } \\
\text { hydroxylase }\end{array}$ & $100-\mathrm{kDa}$ & $87-\mathrm{kDa}$ & $\begin{array}{c}\text { Protein } \\
\text { Illa }\end{array}$ & $\begin{array}{c}\text { Protein } \\
\text { IIlb }\end{array}$ \\
\hline Acetylcholine $(100 \mu \mathrm{M})$ & 305 & 505 & 186 & 238 & 175 \\
Nicotine $(50 \mu \mathrm{M})$ & 285 & 480 & 180 & 222 & 173 \\
Muscarine $(100 \mu \mathrm{M})$ & 112 & 100 & 98 & 104 & 103 \\
Veratridine $(150 \mu \mathrm{M})$ & 273 & 450 & 184 & 196 & 168 \\
Elevated $\mathrm{K}^{+}(40 \mathrm{mM})$ & 290 & 430 & 178 & 231 & 162 \\
A23187 $(10 \mu \mathrm{M})$ & 180 & 240 & 150 & 185 & 146 \\
\hline
\end{tabular}

After prelabeling with ${ }^{32} \mathrm{PO}_{4}$, chromaffin cells were incubated with the indicated test substances for 2 min at room temperature, with the exception of $\mathrm{A} 23187$, which was present for 10 min at $37^{\circ} \mathrm{C}$.

Table 3. Effect of EGTA on acetylcholine-dependent protein phosphorylation in chromaffin cells

\begin{tabular}{lccccc}
\hline & \multicolumn{5}{c}{${ }^{32} \mathrm{P}$ incorporation, \% control } \\
\cline { 2 - 6 } \multicolumn{1}{c}{ Treatment } & $\begin{array}{c}\text { Tyrosine } \\
\text { hydroxylase }\end{array}$ & $100-\mathrm{kDa}$ & $87-\mathrm{kDa}$ & $\begin{array}{c}\text { Protein } \\
\text { IIla }\end{array}$ & $\begin{array}{c}\text { Protein } \\
\text { IIlb }\end{array}$ \\
\hline AcCho alone & 312 & 495 & 182 & 222 & 180 \\
EGTA before AcCho & 101 & 107 & 99 & 98 & 104 \\
EGTA after AcCho & 290 & 160 & 103 & 112 & 108 \\
\hline
\end{tabular}

After prelabeling with ${ }^{32} \mathrm{PO}_{4}$, chromaffin cells were incubated with $50 \mu \mathrm{M}$ acetylcholine (AcCho) at room temperature for $5 \mathrm{~min}$. As indicated, some cells were incubated with EGTA $(1.2 \mathrm{mM})$ either $1 \mathrm{~min}$ prior to addition of acetylcholine or $1 \mathrm{~min}$ after addition of acetylcholine. 
Table 4. Comparison of the effects of acetylcholine, phorbol dibutyrate, and forskolin on protein phosphorylation in chromaffin cells

\begin{tabular}{lccccc}
\hline & \multicolumn{4}{c}{${ }^{32} \mathrm{P}$ incorporation, \% control } \\
\cline { 2 - 6 } Test substance & $\begin{array}{c}\text { Tyrosine } \\
\text { hydroxylase }\end{array}$ & $100-\mathrm{kDa}$ & $87-\mathrm{kDa}$ & $\begin{array}{c}\text { Protein } \\
\text { IIIa }\end{array}$ & $\begin{array}{c}\text { Protein } \\
\text { IIIb }\end{array}$ \\
\hline Acetylcholine & 330 & 480 & 165 & 245 & 175 \\
Phorbol dibutyrate & 285 & 94 & 310 & 199 & 145 \\
Forskolin & 160 & 220 & 98 & 180 & 140 \\
\hline
\end{tabular}

After prelabeling with ${ }^{32} \mathrm{PO}_{4}$, chromaffin cells were incubated with acetylcholine $(100 \mu \mathrm{M}, 60 \mathrm{sec})$, phorbol 12,13 dibutyrate $(1 \mu \mathrm{M}, 10 \mathrm{~min})$, or forskolin $(10 \mu \mathrm{M}, 10 \mathrm{~min})$ at $37^{\circ} \mathrm{C}$.

chromaffin cell proteins IIIa and IIIb (Fig. 4) also produced a major $M_{\mathrm{r}} \approx 18,000{ }^{32} \mathrm{P}$-labeled peptide and, in the case of protein IIIa, a minor $M_{\mathrm{r}} \approx 9,000{ }^{32} \mathrm{P}$-labeled peptide. The phosphorylation of these peptides was increased by acetylcholine treatment.

Effects of Other Secretagogues on Protein Phosphorylation in Chromaffin Cells. As shown in Table 2, nicotine, veratridine, elevated $\mathrm{K}^{+}$, and calcium ionophore A23187 (but not muscarine) mimicked the effects of acetylcholine on protein phosphorylation. Thus, the phosphorylation of tyrosine hydroxylase, $100-\mathrm{kDa}, 87-\mathrm{kDa}$, and protein III is associated with conditions that promote catecholamine secretion in bovine chromaffin cells. The ability of nicotine, but not muscarine, to phosphorylate these proteins reflects the nicotinic nature of cholinergic stimulus-secretion coupling in these cells. The ability of veratridine, elevated $\mathrm{K}^{+}$, and A23187 to mimic acetylcholine in increasing the phosphorylation of these proteins suggests that the effect of acetylcholine on the phosphorylation of these proteins is due to an increase in calcium influx.

Calcium-Dependence of Protein Phosphorylation in Chromaffin Cells. Acetylcholine required extracellular calcium to increase the phosphorylation of tyrosine hydroxylase, 100$\mathrm{kDa}, 87-\mathrm{kDa}$, and protein III, as shown by the fact that the addition of EGTA prior to acetylcholine prevented the effects of the neurotransmitter on phosphorylation (Table 3). Also, the effects of acetylcholine on $100-\mathrm{kDa}, 87-\mathrm{kDa}$, and protein III phosphorylation could be reversed by EGTA. Thus, as shown in Table 3, the acetylcholine-induced phosphorylation of $100-\mathrm{kDa}, 87-\mathrm{kDa}$, and protein III (but not that of tyrosine hydroxylase) was reversed by a 4-min treatment with EGTA, added 1 min after acetylcholine. Catecholamine release was similarly affected by EGTA, added either before or after acetylcholine (data not shown).

Effects of Pharmacological Agents on Protein Phosphorylation in Chromaffin Cells. Treatment of chromaffin cells with phorbol 12,13 -dibutyrate $(1 \mu \mathrm{M}, 10 \mathrm{~min})$ increased the phosphorylation of tyrosine hydroxylase, $87-\mathrm{kDa}$, and protein III, but not that of $100-\mathrm{kDa}$ (Table 4). Treatment of chromaffin cells with forskolin $(10 \mu \mathrm{M}, 10 \mathrm{~min})$ increased the phosphorylation of tyrosine hydroxylase, $100-\mathrm{kDa}$, and protein III, but not that of $87-\mathrm{kDa}$ (Table 4). Phorbol 12-myristate 13-acetate $(1 \mu \mathrm{M})$ and dioctanoylglycerol $(10 \mu \mathrm{M})$, but not $4 \alpha$-phorbol 12,13-dibutyrate $(1 \mu \mathrm{M})$, produced effects similar to those of phorbol 12,13-dibutyrate (data not shown).

\section{DISCUSSION}

An increase in intracellular calcium appears to be a common factor in the ability of secretagogues to increase the phosphorylation of $100-\mathrm{kDa}, 87-\mathrm{kDa}$, and protein III. Thus, it seems likely that phosphorylation of these proteins reflects a set of biochemical sequelae consequent to calcium influx. Each of these proteins is, in fact, a substrate for a specific calcium-dependent protein kinase: $100-\mathrm{kDa}$ is a specific substrate for calcium/calmodulin-dependent protein kinase III (18), $87-\mathrm{kDa}$ is a specific substrate for protein kinase C
(29), and protein III is a specific substrate for calcium/ calmodulin-dependent protein kinase I (30). Thus, one possibility suggested by the present data is that cholinergic activation of chromaffin cells activates an array of calciumdependent protein kinases, the activation of each leading to the phosphorylation of kinase-specific substrates: $100-\mathrm{kDa}$ phosphorylation suggests that acetylcholine increases calcium/calmodulin-dependent protein kinase III activity, 87-kDa phosphorylation suggests that acetylcholine increases protein kinase $\mathrm{C}$ activity, and protein III phosphorylation suggests that acetylcholine increases calcium/calmodulin-dependent protein kinase I activity [and/or cAMP-dependent protein kinase activity $(14,15)]$.

However, as indicated by the pattern of effects of phorbol dibutyrate and forskolin, these postulated effects of acetylcholine on the various protein kinases may not all be mediated directly. For instance, although forskolin did not influence $87-\mathrm{kDa}$ phosphorylation (indicating a failure of cAMP to influence protein kinase $\mathrm{C}$ ), it did increase $100-\mathrm{kDa}$ phosphorylation. Thus, a positive influence of cAMP-dependent processes upon calcium/calmodulin-dependent protein kinase III seems likely. Similarly, although phorbol dibutyrate did not increase $100-\mathrm{kDa}$ phosphorylation (indicating a lack of effect of protein kinase $\mathrm{C}$ activity on calcium/ calmodulin-dependent protein kinase III), it did increase protein III phosphorylation. Thus, a positive influence of protein kinase $\mathrm{C}$ activity on calcium/calmodulin-dependent protein kinase I and/or cAMP-dependent protein kinase seems likely. Such data emphasize that activation of chromaffin (or other) cells may increase activity in multiple second messenger-related pathways and that these pathways are capable of interacting in situ.

Note Added in Proof. Nairn and Palfrey (32) recently showed that $100-\mathrm{kDa}$ is elongation factor 2 , a protein that catalyzes the translocation of peptidyl-tRNA on the ribosome.

This work was supported by Public Health Service Grant NS21550 to P.G. and National Science Foundation Research Grant BNS 84-18302 to M.D.B.

1. Edwards, A. V., Furness, P. N. \& Helle, K. B. (1980) J. Physiol. (London) 308, 15-27.

2. Edwards, A. V. (1982) J. Physiol. (London) 327, 255-277.

3. Viveros, O. H., Arqueros, L. \& Kirshner, N. (1969) Science $165,911-913$.

4. Fenwick, E. M., Fajdiga, P. B., Howe, N. B. S. \& Livett, B. G. (1978) J. Cell Biol. 76, 12-30.

5. Amy, C. M. \& Kirshner, N. (1981) J. Neurochem. 36, 847-854.

6. Meligeni, J. A., Haycock, J. W., Bennett, W. F. \& Waymire, J. C. (1982) J. Biol. Chem. 257, 12632-12640.

7. Haycock, J. W., Meligeni, J. A., Bennett, W. F. \& Waymire, J. C. (1982) J. Biol. Chem. 257, 12641-12648.

8. Haycock, J. W., Bennett, W. F., George, R. J. \& Waymire, J. C. (1982) J. Biol. Chem. 257, 13699-13703.

9. Wu, W. C.-S., Walaas, S. I., Nairn, A. C. \& Greengard, P. (1982) Proc. Natl. Acad. Sci. USA 79, 5249-5253.

10. Albert, K. A., Walaas, S. I., Wang, J. K.-T. \& Greengard, P. 
(1986) Proc. Natl. Acad. Sci. USA 83, 2822-2826.

11. Krueger, B. K., Forn, J. \& Greengard, P. (1977) J. Biol. Chem. 252, 2764-2773.

12. Forn, J. \& Greengard, P. (1978) Proc. Natl. Acad. Sci. USA 75, 5195-5199.

13. Tsou, K. \& Greengard, P. (1982) Proc. Natl. Acad. Sci. USA 79, 6075-6079.

14. Huang, C.-K., Browning, M. D. \& Greengard, P. (1982) J. Biol. Chem. 257, 6524-6528.

15. Browning, M. D., Huang, C.-K. \& Greengard, P. (1987) J. Neurosci. 7, 847-853.

16. Browning, M. D. \& Greengard, P. (1984) Soc. Neurosci. Abstr. $10,59$.

17. Palfrey, H. C. (1983) FEBS Lett. 157, 183-190.

18. Nairn, A. C., Bhagat, B. \& Palfrey, H. C. (1985) Proc. Natl. Acad. Sci. USA 82, 7939-7943.

19. Waymire, J. C., Bennett, W. F., Boehme, R., Hankins, L., Gilmer-Waymire, K. \& Haycock, J. W. (1983) J. Neurosci. Methods 7, 329-351.

20. Batteiger, B., Newhall, W. J. \& Jones, R. B. (1982) J. Immunol. Methods 55, 297-307.

21. Burnette, W. N. (1981) Anal. Biochem. 112, 195-203.
22. Markwell, M. A. K., Haas, S. M., Bieber, L. L. \& Tolbert, N. E. (1978) Anal. Biochem. 87, 206-210.

23. Laemmli, U. K. (1970) Nature (London) 227, 680-685.

24. Imada, M. \& Sueoka, N. (1980) Biochim. Biophys. Acta 625, 179-192.

25. Cleveland, D. W., Fischer, S. G., Kirschner, M. W. \& Laemmli, U. K. (1977) J. Biol. Chem. 252, 1102-1106.

26. Huttner, W. B. \& Greengard, P. (1979) Proc. Natl. Acad. Sci. USA 76, 5402-5406.

27. Elder, J. H., Pickett, R. A., Hampton, J. \& Lerner, R. A. (1977) J. Biol. Chem. 252, 6510-6515.

28. Haycock, J. W., George, R. J. \& Waymire, J. C. (1985) Neurochem. Int. 7, 301-308.

29. Albert, K. A., Wu, W. C.-S., Nairn, A. C. \& Greengard, P. (1984) Proc. Natl. Acad. Sci. USA 81, 3622-3625.

30. Nairn, A. C. \& Greengard, P. (1987) J. Biol. Chem. 262, 7273-7281.

31. Palfrey, H. C., Nairn, A. C., Muldoon, L. L. \& Villereal, M. L. (1987) J. Biol. Chem. 262, 9785-9798.

32. Nairn, A. C. \& Palfrey, H. C. (1987) J. Biol. Chem. 262, 17299-17303. 